\title{
Языковая картина мира: доминанты ментальности
}

Т. Т. Черкашина* Н. С. Новикова**
АННОТАЦИЯ: В статье дается ретроспективный анализ взаимосвязи картины мира и национальной культуры; обосновывается значимость изучения языковой картины мира для понимания специфики национального самосознания; делается вывод о «многомирии», «множественности» языковых картин мира; выявляются особенности русской языковой картины мира, определяется ее смысловой универсум; национальный язык характеризуется как результат коммуникативного сознания этноса; анализируется русская идиоматика, отражающая доминантные черты русской ментальности; исследуются исторические, географические, политические и религиозные факторы, повлиявшие на формирование русского культурного архетипа.
ABSTRACT: Linguistic Picture of the World: Dominants of Mentality. The article offers a retrospective analysis of the interaction between linguistic picture of the world and national culture; substantiates the importance of research into a language picture of the world for understanding the specifics of national identity and shows the multiplicity of linguistic pictures of the world. The authors identify the characteristics of Russian linguistic picture of the world, find its semantic universe defining the national language as a result of cognitive consciousness of ethnos and analyze Russian idioms which reflect the dominant features of the Russian mentality. The paper also explores the historical, geographical, political and religious factors that influenced the formation of the Russian cultural archetype.

Ключевые слова: языковая картина мира, национальная культура, культурный архетип, русская ментальность Keywords: linguistic picture of the world, national culture, cultural archetype, Russian mentality 
* Государственный университет управления. Москва, Россия. ttch2004@yandex.ru *夫 Российский университет дружбы народов. Москва, Россия natalynov@yandex.ru

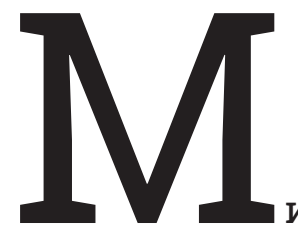

ир человека - это мир культуры. Ментально культура представлена картиной мира. Картина мира - это целостный образ, складывающийся в голове человека в процессе познавательной деятельности, но это не зеркальное отражение реального мира. Картина мира - это реальность человеческого сознания. «Это гетерогенные (разнородные), гетерохронные (познаваемые в разные отрезки времени), гетеросубстрактные (имеющие разную когнитивную основу) сведения о мире». Картину мира можно трактовать как ментальную репрезентацию культуры и, как следствие, ей во многом свойственны характеристики, присущие культуре как феномену: целостность, комплексность, историчность, многообразие, полиинтепретируемость, способность к эволюции и т.п.

Термин "картина мира"впервые был предложен Л. Витгенштейном в аспекте философии и логики². Понятие картина мира, прочно войдя в разряд рабочих терминов многих наук, конкретизируется дополнительными определениями: научная, общенаучная, частнонаучная, естественнонаучная, историческая, физическая, биологическая, языковая, национальная и др. Человек пытается заменить реальный мир картиной, созданной в себе, т.е. в своем сознании. Особое место среди картин мира принадлежит языковой картине мира, покрывающей все сферы человеческого знания и оказывающейся в системе различных картин мира наиболее долговечной, устойчивой (разумеется, лишь на том или ином конкретном временном срезе), стандартной, ибо «воспроизводимы» именно стандартные единицы языка,

\footnotetext{
1.Черкашина Т.Т. Менеджер как субъект языка и культуры: Монография. М.: Издательский дом «Додэка-XX|», 2008. С.57.

2 Витгенштейн Л. Избранные работы/ Пер. с нем. - М.: Издательский дом «Территория будущего», 2005.
} 
ставшие узуальными. Видимо, именно поэтому изучение языковой картины мира оказалось в последние годы особенно значимым для всех сфер научного знания, и в первую очередь - для философии, для познания сущего, бытия, ибо еще Ж.-П. Сартр писал: «Так как я открыл для себя мир через язык, я долгое время принимал язык за мир» (Цит. по $\left.{ }^{3}\right)$

Известно, что в традиции языкознания преобладал путь исследования от именуемой реалии (элемента, предмета действительности) - к ее номинации, словесному обозначению, к слову. Действительный окружающий человека мир «фиксируется» в словаре. На этом зиждятся идеи традиционной философской теории «отражения». Еще Вольтер в 1769 г. озаглавил свое женевское издание философского словаря «Разум по алфавиту», а А.Франс в статье, опубликованной в 1892 в журнале «Литературная жизнь», называл словарь «книгой книг», сравнивая его с вселенной, представленной в алфавитном порядке, и подчеркивая, что словарь сам по себе включает в себя все остальные книги, и нужно только извлечь их из него. Добавим, что словарь включает в себя и все сущности, в той или иной мере познанные (или хотя бы замеченные) человеком.

В XX веке в связи с осознанием бесконечности всего сущего, а также осмыслением того, что уже в языке, в самой словесной номинации представлен некий аспект познания именуемой реалии (предмета, вещи, абстрактного понятия и т.п.), был предложен иной, в принципе противоположный, путь исследования сущего (бытия, мира): от слова - к вещи, обозначенной словом, или, иначе, путь познания сущего «через слово», с помощью осмысления его семантики. Сегодня не только философия, но и лингвистика стремятся извлечь из словаря данные о сущем, о реалиях. Иначе говоря, стоит задача через «вселенную» словаря языка познать вселенную как реальность.

Любой национальный язык представляет собой универсальное, глобальное знание как результат работы

з Черкашина Т.Т. Менеджер как субъект языка и культуры: Монография. М.: Издательский дом «Додэка-XX|», 2008. С.38. 
коллективного сознания. Существуют разные виды человеческого сознания: индивидуальное сознание отдельного человека, коллективное обыденное сознание нации, научное сознание. «Каждый язык, - утверждал В. фон Гумбольдт, - описывает вокруг народа, которому он принадлежит, круг, откуда человеку выйти дано лишь постольку, поскольку он тут же вступает в круг другого языка»4. По В. фон Гумбольдту, в процессах категоризации мира языку принадлежит ведущая роль, поскольку он представляет собой «мир, лежащий между миром внешних явлений и внутренним миром человека». Позднее ученый назовет этот промежуточный мир «подлинной реальностью» (wahre Welt). Э. Сепир считал, что мир строится на лингвистических привычках этноса, человек приспосабливается к миру с помощью языка, который выступает посредником для общения в социуме ${ }^{5}$.

Термин языковая картина мира (ЯКМ) был введен в научный оборот Л. Вайсгербером. К понятию ЯКМ обращались отечественные ученые: Ю.Д. Апресян, Ю.Н. Караулов, Г.В. Колшанский, Е.С. Кубрякова, В.А. Маслова,В.И. Постовалова, Н.Ю. Шведова и др. Приведем некоторые определения ЯКМ:

ЯКМ - это «зафиксированная в языке и специфичная для данного языкового коллектива схема восприятия действительности», «определенный универсальный и в то же время рационально специфичный способ восприятия и организации (концептуализации) мира, в котором выражаемые значения складываются в единую систему взглядов (коллективную философию), которая навязывается в качестве обязательной всем носителям языка» (Ю.Д. Апресян).

ЯКM - наиболее глубинный слой общенародной картины мира, в котором запечатлеваются результат видения мира человеком с помощью языка и который ориенти-

\footnotetext{
4 Гумбольдт В. Избранные труды по языкознанию/ Пер. с нем. - М.: «Прогресс», 1984. С.80.

${ }^{5}$ Сепир Э. Избранные труды по языкознанию и культурологии/ Пер. с англ. - М.: «Прогресс», 2002.
} 
рует человека на определенное отношение к миру и ориентации в нем (В.И. Постовалова).

ЯКМ - это «выработанное вековым опытом народа, осуществляемое средствами языковых комбинаций изображение всего существующего как целостного и многочастного мира. В своем строении и осмысляемых языком связях своих частей представляющего, во-первых, человека, его материальную и духовную жизнедеятельность и, во-вторых, все то, что его окружает: пространство, время, живую и неживую природу, область созданных человеком мифов и социум» (Н.Ю. Шведова) (Цит. по6)

Таким образом, можно говорить о так называемом «многомирии» ${ }^{7}$ о множественности ЯКМ: о научной ЯКМ (НЯК), о ЯКМ национального языка (ЯКМНЯ), о ЯКМ отдельного человека. Картина мира формирует тип отношения человека к миру: природе, людям, к самому себе, к труду, к нравственным устоям, национальным традициям, определяет его место в культурном пространстве и формирует отношение к нему.

Проанализировав приведенные выше определения, можно выделить следующие инвариантные составляющие ЯКМ: а) модель, схема восприятия действительности (иначе говоря, совокупность знаний); б) выработанная вековым опытом народа как результат познания; в) отраженная в языке; г) ориентирующая человека на определенное отношение к миру; д) изменчивая во времени; е) национально специфичная; ж) наивная, в отличие от научной картины мира.

Таким образом, можно сказать, что наше миропонимание в какой-то степени находится в плену у ЯКМ. Не случайно Л. Витгенштейн утверждал, что «границы моего языка означают границы моего сознания»․ А М.Цвета-

\footnotetext{
${ }^{6}$ Сабитова 3.К. Лингвокультурология: Учебник. - М.: «Флинта-Наука», 2013. C.52.

7 Новикова Н.С., Черемисина Н.В. Многомирие в реалии и общая типология языковых картин мира. / Филологические науки, №1. - М.: ж. «Филологические науки», №1, С.40-49.

${ }^{8}$ Витгенштейн Л. Избранные работы/ Пер. с нем. - М.: Издательский дом
} 
ева в письме В. Черновой, написанном в 1925 году, заметила, что «... иные вещи на ином языке не мыслятся». Национальный характер, национальная ментальность получают отражение в языке. По мнению В.Ф. Чесноковой ${ }^{9}$, национальный характер - это «общество внутри нас», существующее в виде однотипных для представителей одной и той же культуры реакций на типичные ситуации, которые вызывают в сознании носителя языка всю гамму чувств, являющихся импульсом к привычным и одобряемым национальными традициями речевым и иным действиям. Этнос в целом, как и характеризующая его национальная культура, есть совокупность общего и специфического.

Каждый человек имеет свою индивидуальную картину мира. Загадочную русскую душу пытались разгадать зарубежные исследователи и продолжают разгадывать. «Русская душа - это нестабильное равновесие между желаемым и действительным, где спонтанно возникающее чувство совести каждый раз по-разному оценивает происходящее вокруг, заставляя носителя этой души постоянно мучиться и страдать от всего им уже сделанного и даже не сделанного. Понять это определение правильно можно, будучи хоть немного русским, в этом и есть тайна: то, что они, русские, сами не понимают, мы стараемся понять за них, и, конечно, ... ничего не понимаем», - писал А. Виноградов ${ }^{10}$. Русский философ Н.А. Бердяев утверждал, что «русская национальная мысль чувствует потребность и долг разгадать загадку России, понять идею России, определить ее задачу и место в миpe»11.

По выражению А. Вежбицкой, каждый язык образует свою семантическую вселенную: «Не только мысли могут быть подуманы на одном языке, но и чувства могут быть испытаны в рамках одного языкового сознания,

\footnotetext{
«Территория будущего», 2005. С.180.

9 Чеснокова В.Ф. Язык социологии: Курс лекций. - М.: «ОГИ», 2010. С.273.

${ }^{10}$ Виноградов А.A. //worlds.ru

11 Бердяев Н.А. Душа России/ Судьба России// krotov.info
} 
но не другого» ${ }^{12}$. Так, двум русским словам смех и хохот соответствует в английском языке одно слово - laughter (здесь и далее - пример и комментарии А.Вежбицкой). При этом русское слово хохот имеет особую сочетаемость, проявляющую специфику его значения,- умирать (помирать) от хохота, чуть не умереть от хохота. Сочетаемость свидетельствует о громкости, неудержимости хохота. К тому же слово хохот означает длительное действие. По наблюдениям Вежбицкой, об этом свидетельствуют сочетания кататься от хохота, с ног валиться от хохота, на глазах слезы выступили от хохота и др. А отмеченное автором своеобразие сочетаемости этого слова с прилагательными (хохот - веселый, громкий, здоровый, дружный, раскатистый) приводит исследователя к мысли о том, что " в русской культуре громкий и несдержанный хохот не рассматривается... с каким-либо неодобрением", а "напротив того, он считается "здоровым"13. Однако, по нашим данным, в дореволюционной России в интеллигентной, в частности дворянской, среде чрезмерно громкий, "несдержанный" хохот, как и чрезмерно громкая речь на улице и в других общественных местах, считался признаком недостаточной воспитанности, дурного тона.

В то же время замеченная А.Вежбицкой положительная окраска однокоренных слов хохотун и хохотунья (добавим, что эти слова, как и не упомянутый автором синоним последнего слова - "хохотушка, имеют разговорную стилевую окраску), вероятно, действительно связана с тем, что "хохот должен выражать неподдельно "хорошие чувства": не случайно сочетания типа горький хохот, саркастический хохот не типичны для русского языка ${ }^{14}$. Добавим также, что в положительной окраске слов хохотун, хохотунья и хохотушка видится и выражение непритворности, открытости, искренности и даже широты русского характера.

\footnotetext{
12 Вежбицкая А. Семантические универсалии и описание языков. - М.: «Языки русской культурв», 1999. С. 527.

13 Там же, С. 528.

14 Там же С. 529
} 
Смысловой универсум русского языка образуют следующие признаки:

1. Эмоциональность и широта русской души, о чем свидетельствует высокий эмоциональный накал русской речи, богатство языковых средств для выражения эмоций. Ни в одном языке нет такого разнообразия суффиксов субъективной оценки: душенька, доченька, голубчик; миленький, родненький; ручищи, домище, холодище и др. Широта души может интерпретироваться как максимализм. Вспомним стихотворение А.К.Толстого, которое в первоначальном варианте имело значимое заглавие - "Русская душа" (об этом свидетельствует сохранившийся среди писем автора к В.Д. Давыдову список данного стихотворения, представленный с упомянутым заглавием):

Коль любить, так без рассудку,

Коль грозить, так не на шутку,

Коль ругнуть, так сгоряча,

Коль рубнуть, так уж сплеча!

Коли спорить, так уж смело,

Коль карать, так уж за дело,

Коль простить, так всей душой,

Коли пир, так пир горой!

2. "Иррациональность», подчеркивающая ограниченность прагматического мышления: Русский Бог авось-небось - да как-нибудь; Авось пронесет, Бог не выдаст - свинья не съест.

3. Смирение, покорность, связанные с неагентивностью, фатализмом, синдромом судьбы: надеяться/полагаться на авось (т.е. наугад, на удачу, ничего не обдумывая заранее); на всякий случай; угораздило и др.

4. Приверженность морализированию как стремление абсолютизации добра и зла: Худо жить без ласкового слова; Добро не лихо, ходит по миру тихо; Бедного обижать - себе добра не желать и др. 
5. Полярность оценок, неумение и нежелание идти на компромисс: Или пан, или пропал; Все или ничего и др.

Непредсказуемость русской души, кажущаяся иностранцам непостижимой, объясняется также ее расположенностью на стыке двух великих цивилизаций Востока и Запада. Россия является и мостом, и барьером, поэтому ученые называют Россию то азиатской, то европейской страной. По этому поводу Н.А. Бердяев писал: « ... пейзаж русской души соответствует пейзажу русской земли, та же безграничность, бесформенность, устремленность в бесконечность, широта... В душе русского народа остался сильный природный элемент, связанный с необъятностью русской земли, с безграничностью русской равнины»15.

Русский народ сформировался на базе славянских и неславянских племен, соединив в себе, казалось бы, несоединимое, цементируя это на славянской основе. Приняв христианство, славяне приспособили его к язычеству, что сохранилось до сих пор. Но языковая общность не является синонимом слова народ. Народ может и не быть объединен одним языком (как, например, в Швейцарии). Даже если предположить, что конкретный язык - это действительно национальный язык, нет никаких оснований утверждать, что носители этого языка считают себя единым сообществом. Достаточно вспомнить такие обозначения, как пангерманизм, панславянизм, евроцентризм, глобализм и проч. Все эти понятия мыслимы только вне национальных рамок. Между тем, находясь за пределами родного культурного пространства, человек, отвечая на вопрос, кто он такой, без тени сомнений отвечает: я немец (не баварец, германец, европеец, протестант); я русский (не башкир, бурят, чуваш, белорус и проч.); я китаец и т.д.

Как только речь заходит о нации, становится не важно, является ли человек чисто географически жителем Баварии или Рейнской области, не значимы также и его социальный статус и религиозная или партийная

$\overline{15}$ Бердяев Н.А. Истоки и смысл коммунизма// vehi.net 
принадлежность. Так, различия между диалектами ву, кантонез, хокиен, относящимися к китайскому языку, столь существенны, что европейцы немедленно начинают расспрашивать китайцев, кто они по национальности. А расхождения между македонским, сербским, словенским, хорватским или чешским и словацким, напротив, так ничтожны, что заставляют неискушенного в лингвистических тонкостях человека предположить, что это один язык. Способность к взаимопониманию вырабатывается в процессе социализации. Принцип взаимопонимания, скорее всего, результат внушения, имеющего главной целью создать в сознании носителей языка идею национальной принадлежности. Не секрет, что границы между наборами языковых средств и тем, что именуется языками, в Центральной Европе подчас оказываются размыты, поскольку у нидерландского, нижненемецкого и среднефранкского налажен исключительно интенсивный межъязыковой обмен. То же самое относится и к славянским языкам. Ю.В. Бромлей ${ }^{16}$, определяя этнос как «квант» специфической культурной информации, в то же время подчеркивает неправомерность сведения культурного единства этнических образований к совокупности некоторых особенностей. На это же, в сущности, указывает А. Моль: «Рисовать тип культуры как набор характерных черт свойственно только карикатуре или жанровому очерку ${ }^{17}$. О чем это говорит? Прежде всего о том, что среди факторов, способствующих возникновению и закреплению национально-культурной специфики народа, ученые выделяют природно-географические, социально-исторические, трудовые, культурно обусловленные факторы, определяющие формирование ЯКМ.

Сегодня все больше говорят о динамическом понятии культуры, в котором, в отличие от классического, большое значение придается субъективным интерпретациям, но по-прежнему главным действующим лицом ЯКМ является «его величество русский язык» (С.Г. Тер-Минасова). Данный подход представляет картину мира в ка-

\footnotetext{
${ }^{16}$ Бромлей Ю.В. Этнос и этнография: Учебник. - М.: «Высшая школа», 1980.

17 Моль А. Социодинамика культуры. - М.: «Прогресс», 1973. С.16.
} 
честве «невидимого рюкзака»: человек в современном обществе носит с собой культурные знания своей языковой и национальной группы как «культурный багаж» и обращается с ним по своему усмотрению в зависимости от конкретной ситуации, т.е. постоянно его переосмысливает. Следует отметить, что в глобализирующемся мире отдельный человек одновременно может соприкасаться не с двумя, а с несколькими национальными культурами. Важно, чтобы личность владела этими моделями ЯКМ. Как известно, при общении носителей различных культур, которых сейчас принято называть межкультурными личностями (Клод Ажежа, например, ввел понятие диалоговый человек) или языковыми личностями (Ю.Н. Караулов), может возникнуть так называемый межкультурный шок, потому что в процессе взаимодействия каждый человек вносит в ситуацию общения свой коммуникативный (культурный) стиль. Под коммуникативным стилем понимается коммуникативные системы, включающие вербальные, невербальные, паравербальные и экстравербальные компоненты, обусловленные данной конкретной культурой. Раздельно рассматривать язык и культуру нельзя, потому что язык - органическая часть культуры, складывающиеся в ЯКМ. «Факты языка - это те же факты культуры (perfekt - такой же факт немецкой культуры, как и Кельнский собор; совершенный вид глагола - такой же факт русской культуры, как матрешка»), - считает Е.И. Пассов ${ }^{18}$. В диалоге с незнакомым, в контакте с «чужим» выделяется именно индивидуально-национальное, стереотипное представление о конкретном народе, о данной стране и ее культуре. В процессе межкультурного диалога, выходя за рамки родной культуры, присваивая другую культуру, копируя ее, носитель конкретного национального языка со сложившейся национальной картиной мира не отказывается от своей ЯКМ. Как отмечает В.С. Библер,»старое знание включается в знание новое» (Цит. по 19: расшатывание монокультурного сознания инди-

\footnotetext{
18 Пассов Е.И. Технология диалога культур в иноязычном образовании: Монография. Липецк, 2005. С.22.

19 Черкашина Т.Т. Языковые маркеры в практике коммуникативного лидерства как
} 
вида, когда представитель одной культуры при контакте с представителем другой культуры пытается понять его систему восприятия мира, логику мышления, ценностей, действий, приводит к попыткам включить эту иную культурную модель, встроить ее в культурное поле своей родной культуры.

С.Г. Тер-Минасова утверждает, что «между предметом и словом, обозначающим этот предмет, стоит понятие, обусловленное культурой и видением мира данным речевым коллективом»20. Любое слово в нашем сознании, точно так же, как и в речевой практике, по отдельности не существует. Так, ассоциативный потенциал слова земля в повести В. Распутина «Прощание с Матерой» определяется значением родная. Родная, т.е. та, где «каждый камень еще до твоего рождения предчувствовал и ждал тебя, и тут каждая травка по весне несет тебе что-то в остережение или поддержку от былых времен, и во всем за тобой родовой догляд».

Лексика является способом отражения этнокультурной картины мира, поскольку слово - это продукт и инструмент культуры, который оказывает решающее влияние на формирование мировосприятия человека. «Нет сомнения, что слова, словосочетания, фразеологические единицы всех видов, т.е. все то, из чего складывается лексический состав языка, играют основную роль в реализации функции языка как орудия культуры и средства формирования личности», - считает С.Г. Тер-Минасова ${ }^{21}$.

Устное народное творчество традиционно является наиболее авторитетным источником для реконструкции национальной ЯКМ в ее обыденно-наивном аспекте существования. Паремии несут в себе моральные ценности и представляют внутренние истоки культуры общества, почерпнутые из исторического опыта, воссоздавая национально-социальную психологию народа. Оценивая паремии русского языка, А.М.Горький пи-

\footnotetext{
элемент эффективного управления// Вестник Московского университета. Серия

20 Управление (государство и общество). 2015. №2. С. 112-127.

21 Тер-Минасова С.Г. Язык и межкультурная коммуникация: Монография. М.: «Слово», 2000. С.139.
} 
сал, что «в простоте слова самая мудрость, пословицы и песни всегда кратки, а ума, чувства вложены в них на целые книги». Пословица как одна из самых употребительных в речи разновидностей паремий особенно интересна для исследования национальных ментальных и культурных стереотипов сразу в нескольких ракурсах: 1) с точки зрения особенностей семантической структуры пословиц, способствующей аккумуляции, хранению и трансляции культурно значимой информации, а также 2) для рассмотрения основных прагматических установок, действующих практически независимо от конкретных социально-исторических условий и не теряющих своей актуальности напротяжении сотни лет.

Этнические стереотипы представляют собой упрощенный, схематизированный, эмоционально окрашенный и достаточно устойчивый образ какой-либо этнической общности, мнение обобщенного характера о той или иной этнической группе, распространяемое на всех ее представителей. При этом принято различать автостереотипы, т.е. образы, которые этническая группа имеет о самой себе, и гетеростереотипы, т.е. образы, которые группа имеет о другой (чужой) группе. Несмотря на зачастую настороженное отношение к чужестранцам, уже древнерусское общество отличалось открытостью межэтническим контактам и обширностью международных связей. Закрытость общества иностранным влияниям, отрицательное отношение к иностранцам в эпоху Московского царства в дальнейшем сменяется открытостью ко всему иностранному, которые после Петра I становятся главной чертой русской культуры. Как известно, древнерусская народность складывалась в смешении, по меньшей мере, трех этнических компонентов - славянского, балтского и финно-угорского, с заметным участием также германского, тюркского и северо-кавказского. Это предопределило открытость русских пришельцам, состав которых исторически менялся, к чужим культурам. Под влиянием контактов с иностранцами обогатилась и русская материальная и духовная культура. Например, без татар не было бы системы русской государственности, «русских шапок», крепких руга- 
тельств, сапог, ямщиков, кнута, «русской тройки».

Следует отметить, что на протяжении всей истории России иностранцы успешно интегрировались в российское дворянство. В допетровское время четверть знати имела татарские корни. Так, третий русский царь Борис Годунов отсчитывал свою родословную от татарского мурзы Чета, крещенного в 1310-х гг. с именем Захарии (Чет-Захария относился к царскому роду Чингизидов). Из татар происходили русские дворяне Ермоловы, Давыдовы, Черкасские, Дашковы, Апраксины, Державины, Арсентьевы, Карамзины и др. Из немцев - Хвостовы, Беклемишевы, Орловы, Левшины, Марковы, Востоковы, Толстые, Пушкины, Протопоповы и др.

Особенно много немцев жило на Руси в XVIII веке. Однако немцами в то время могли называть и поляков, и голландцев, и французов. Согласно ряду авторов можно предположить, что образ "немца» воспринимался русским политическим и обыденным сознанием не как экзоэтноним, а скорее, в значении «немой» (иной) и «не мой» (чужой) и тем самым служил для создания внешних ориентиров русской национальной идентичности. По М.Фасмеру, древнерусское «ньмьць» - «человек, говорящий неясно, непонятно»: «иностранец», ньмьчинъ, «немец, любой иностранец». Представления о немцах, принявшие характер этностереотипов, складывались в России постепенно, причем некоторые из них оказались достаточно устойчивыми. Пиво, трубка, табак как обязательные внешние признаки не только немецкого быта, но и самих немцев, воспринимались почти как их органические свойства. Представление о таких чертах немцев, как хитрость (Немец хитер: обезьяну выдумал, Хитра лиса, хитрее лисы - немец), способность приспосабливаться к ситуации (Немец, что верба: куда ни ткни, тут и принялся), склонность руководить (Родом из немчин, а указывать горазд), а также расчетливость, переходящая в скупость, аккуратность, перерастающая в педантизм (Настоящий немец), всегда традиционно противопоставлялось исконным качествам русских. Не вызывали симпатии у последних и предусмотрительность, и практицизм немцев, а также их чрезмерные знания ( $y$ немца 
на все струмент есть; Немецкая [т.е. точная, школярная] ученость).

Вместе с тем в представлениях о немцах XVIII-XIX вв. сквозит добродушный юмор, спокойное признание факта существования рядом человека иного склада, чем русский (Немец без штуки с лавки не свалится), и наивное убеждение, что русский народ якобы обладает чемто, что выше и учености, и хитрости, и ловкости немца.

Христианская мораль оказала мощное воздействие на формирование аксиологического плана национальной картины мира, привнеся в нее особенное представление о человеке, сотворенном «по образу и подобию» Бога-слова: Слово слову рознь: словом Господь мир создал, словом Иуда предал Господа. Именно христианство задало вектор новому отношению к Другому.

«Иконой Православия» называл церковно-славянский язык Ю.А. Успенский. Язык выкристаллизировал представления человека о мире и о его месте в нем. Ключевыми словами русского самосознания, которые и легли в основу «орфографии», «грамматики» и «логики» культуры как семиотической системы, впитавшей в себя своеобразие нравственного кодекса народа, стали со-борность, совесть, правда, воля и др. Так, концепт со-борности, понимаемый как со-причастность, со-чувствие, со-переживание, со-вместность любых действий или усилий, нашел свое отражение в таких пословицах, как Дружного стада и волк не берет; Народ, не знающий единства, с нуждой дружит, народ, сильный единством, со счастьем дружит; Люби ближнего как себя; Любящих и Бог любит; Не имей сто рублей, а имей сто друзей; Чти отца твоего и мать твою; Друга не узнаешь в счастье, враг не скроется в несчастье; Близкий сосед лучше дальней родни; Был у друга, пил воду - показалась слаще меду и др. Заметим, что идея соборности - одна из ключевых идей русской классической философии. Отечественные философы отмечали, что в России соединяются два мира, две цивилизации. Задолго до появления термина менталитет в зарубежной философии отечественные мыслители сосредоточили свои усилия на анализе «души обществен- 
ного целого», со-борности, воспринимая ее как единый комплекс специфических нравственно-психологических черт русских: а) А. Хомяков (1804-1860 гг.) понимал соборность в качестве особой ценности русской культуры в противовес католицизму и протестантизму, проповедовавших, с одной стороны, покорность, послушание, а с другой - индивидуализм; б) К. Аксаков (1817-1860 гг.) ратовал за органическое включение личности в русскую общину, в которой личность свободна, подобно хористу в хоре; в) Ю.Самарин (1819-1876 гг.) понимал под идеей соборности отказ личности от ее «самости», сознательное подчинение вере, Богу; г) С. Трубецкой (1862-1905 гг.) подчеркивал «природную соборность сознания» русских: «Мы, люди... держим внутри себя собор со всеми».

Соборность как «сгусток русского духа» очень важна для понимания специфики отечественной культуры. Это подтверждается многогранностью ее истолкования: это и специфика российской духовности («тайна русской души»); и внутренний мир человека («вложить всю душу»); и сам человек как главная персона («душа общества»); и свойства ее характера («добрая душа»); и просто человек («в доме ни души»); и его бессмертное начало («подумать о душе»); и мера открытости индивида («со всей душой»); и социально-духовная смерть человека («мертвые души») и т.д.

Получив мощную «прививку» православия, национальная культура, несмотря на годы безверия и гонений, сохранила исконное духовное начало. Так, анализируя в статье «Русский человек» основания русского национального самосознания, Г.П. Федотов писал: «Русский славянин и в XIX веке еще не оторвался вполне от матери-земли... Природа для него не пейзаж, не обстановка быта и уж, конечно, не объект завоевания. Он погружен в нее как в материнское лоно, ощущает ее всем своим существом, без нее засыхает, не может жить... Моральный закон личности, ее право на свою совесть, на свое самоопределение просто не существует перед законом жизни. В нравственной сфере это создает этику мира, коллекти- 
ва, круговой поруки» (Цит. по 22$)$.

Доминантной чертой русской ментальности, по мнению авторитетных ученых, был и остается приоритет морали над правом. Так, в «Толковом словаре живого великорусского языка» В.И. Даля статья, посвященная описанию слова совесть является наиболее обстоятельной: совесть - 1) нравственное сознание, нравственное чутье или чувство в человеке; 2) внутреннее сознание добра и зла; 3) тайник души, в котором отзывается одобрение или осуждение каждого поступка; 4) способность распознавать качество поступка; 5) чувство, побуждающее к истине и добру, отвращающее ото лжи и зла; 6) невольная любовь к добру и к истине; 7) прирожденная правда, в различной степени развития и т.д.: От человека утаишь, от совести (от Бога) не утаишь. Совесть мучит, снедает, томить или убивает; Совесть спать не дает. К кафтану (к коже) совести не пришьешь

Переживание собственного несовершенства и стремление соответствовать нравственным нормам, нашло отражение в многочисленных пословицах, подтверждающих большую роль данного концепта в русской ЯКМ:

\begin{tabular}{|c|c|}
\hline $\begin{array}{l}\text { Совесть как } \\
\text { внутренний } \\
\text { «цензор» }\end{array}$ & $\begin{array}{l}\text { Глаза - мера, душа - вера, совесть - порука; В ком } \\
\text { стыд, в том и совесть; В ком совесть не чиста, тому и } \\
\text { тень кочерги виселица; От человека утаишь, от } \\
\text { совести не утаишь; Что того и совестить, у кого нет } \\
\text { совести и др. }\end{array}$ \\
\hline $\begin{array}{l}\text { Отношение к } \\
\text { закону и } \\
\text { праву }\end{array}$ & $\begin{array}{l}\text { Жизнь дана на добрые дела; Закон - паутина: шмель } \\
\text { проскочит, муха увязнет; То-то и закон, как судья } \\
\text { знаком; Была бы спина, найдется и вина; добрые } \\
\text { дела; Закон - паутина: шмель проскочит, муха } \\
\text { увязнет; То-то и закон, как судья знаком; Была бы } \\
\text { спина, найдется и вина и др. }\end{array}$ \\
\hline
\end{tabular}

22 Там же, С. 140. 
К ключевым понятиям русской ЯКМ относится также концепт правда как нравственный идеал, как истина в образе, справедливость, правосудие (по В.И. Далю). В народном сознании правда ассоциировалась с любовью-жалостью к ближнему:

\begin{tabular}{|c|c|}
\hline $\begin{array}{l}\text { Правда как } \\
\text { основа } \\
\text { ментальности }\end{array}$ & $\begin{array}{l}\text { Где честь, там и правда; Правда из огня, из воды } \\
\text { спасает; Правда глаза колет; Стой за правду горой; За } \\
\text { правду не судись - скинь шапку да поклонись; Не } \\
\text { ищи правды в других, коли ее в тебе нет и др. }\end{array}$ \\
\hline $\begin{array}{l}\text { Отношение к } \\
\text { правде }\end{array}$ & $\begin{array}{l}\text { Правда, что шило в мешке; Правда всегда наружу } \\
\text { выйдет; от правды отстать, куда пристать? Правда } \\
\text { хорошо, а счастье лучше; Правдой жить - палат } \\
\text { каменных не нажить; Бог правду видит; По правде } \\
\text { тужим, а кривдой живем и др. }\end{array}$ \\
\hline
\end{tabular}

Согласно теории американскоголингвиста иантрополога Э. Сепира и его ученика Б. Уорфа, которая получила название «гипотезылингвистическойотносительности», само восприятие человеком мира, в котором он живет и действует, также детерминировано языком и культурой. Суть концепции состоит в том, что люди, говорящие на разных языках, живут в отличающихся друг от друга мирах, поскольку в сознании человека реальный мир существует так, как это находит свое отражение в языке. Отечественный ученый, филолог, семиотик Ю.С. Степанов дает метафорическое определение понятию концепт, утверждая, что концепт - это «как бы сгусток культуры в сознании человека; то, в виде чего культура входит в ментальный мир человека. И с другой стороны, концепт - это то, с помощью чего человек - рядовой, 
обычный человек, не «творец» культурных ценностей сам входит в культуру, а в некоторых случаях и влияет на нее» ${ }^{23}$.

Мифолог ичность, «сказочность» русской ЯКМ, которую отмечают многие ученые, включает в себя также такие концепты, как терпение, коллективизм, смелость, решительность, самостоятельность, потому что именно они демонстрируют укорененность в русском языковом сознании представлений о своем «Я» в неразрывной связи с общиной, что тоже зафиксировано в корпусе пословиц: Мир не без добрых людей; На весь мир не угодишь; На миру и смерть красна; Сто голов - сто умов; Свои люди - сочтемся; В тесноте, да не в обиде; Смелость города берет; Волков бояться - в лес не ходить; На Бога надейся, а сам не плошай и др.

Коренные, архетипичные черты русской ментальности, в которых отражены особенности национального самосознания и социокультурной практики, обусловили самобытность русской ЯКМ, ориентированной на эмоциональную открытость, истинность и содержательную значимость. Вот, к примеру, как описывает концепт любовь известный русский философ В.В. Розанов: «Мы рождаемся для любви. И насколько мы не исполнили любви, мы томимся на свете. И насколько мы не исполнили любви, мы будем наказаны на том свете. Любить - значит «не могу без тебя быть», «мне тяжело без тебя», «везде скучно, где не ты». Это внешнее описание, но самое точное. Любовь вовсе не огонь (часто определяется), любовь - воздух. Без нее - нет дыхания, а при ней «дышится легко». Вот и все» ${ }^{24}$.

Именно в России родились оригинальные идеи и особое миропонимание, которых нет ни в восточной, ни в западной культурах, что позволило Ф.И. Тютчеву всего в четырех строчках своих философских стихов задать иностранцам задачу, которую они до сих пор не могут решить:

\footnotetext{
${ }^{23}$ Степанов Ю.С. Константы. Словарь русской культуры. - М.: «Слово», 1997. С.40.

${ }^{24}$ Розанов В.В. Опавшие листья. Короб первый. // Розанов В.В. Уединение. - М., «Языки славянских культур», 1990. С.158
} 


\section{Умом Россию не понять, \\ Аршином общим не измерить: \\ У ней особенная стать - \\ В Россию можно только верить.}

Значительное влияние на формирование русского культурного архетипа, как отмечал еще В.О. Ключевский, оказала природа России. Территория севера Евразии - это самая неблагоприятная в климатическом отношении часть Земли. Российскую природу отличают суровость, монотонный ландшафт Восточно-Европейской равнины, огромная территория, слабая заселенность, колебания и неустойчивость климата, трудность «окультуривания», в отличие от Западной Европы. Эти условия формируют такие качества человека, как способность к чрезмерному, но кратковременному напряжению сил, но при этом не воспитывается привычка к ровному, умеренному, постоянному труду; склонность к солидарным коллективным усилиям, отсюда установка «навалиться всем миром»; отсутствие сформировавшегося чувства суверенного хозяина своей земли, заботы о ней вследствие наличия общины, помещичьего землевладения; слабое развитие трудовой этики; не вполне сформировавшиеся черты, связанные с развитыми институтами частной собственности. Опыт суровой жизни вырабатывал у россиян уважение к природным стихиям, удивление и восхищение красотой и гармонией природы. Но он же формировал и пассивно-созерцательное, фаталистическое отношение к миру, сочетавшееся в то же время под влиянием тяжелой борьбы за существование, со стихийно-реалистическим отношением к жизни. Невозможность предварительных расчетов и прямого движения к цели отразились на складе ума, манере мышления великоросса. В его мышлении доминирует интуитивизм, а не рационализм, у него больше восточной (византийской) иррациональности, чем западной рациональности, и поэтому эмоции у него преобладают над разумом, страсти - над интересами. Он чаще идет за «голосом сердца», чем за рассудком, и у него превалирует наглядно-образное и наглядно-действенное мыш- 
ление, тогда как на Западе - вербально-логическое. В.О. Ключевский указывал и на такие черты россиян: осторожность, колебания, неуверенность в себе, необщительность, «крепость задним умом», им легче преодолеть трудности, неудачу, чем освоиться с мыслью о своем величии.

Русский культурный архетип испытал влияние социоцентризма, так как особую роль в развитии общества в России играло государство. Как следствие восточного влияния отношения в обществе приобрели министериально-подданический характер. Поэтому поведение человека в общественной и личной жизни стало оцениваться в соответствии с его чином, т.е. местом в социальной иерархии. Сложилась холопская психология и нравственность: безответственно пренебрежительная по отношению к своим подданным и рабски уничижительная - к своему господину; при этом затрудняется осознание себя личностью и доминирует стремление «быть как все», существует развитое чувство конформизма и, соответственно, способность приспосабливаться к невыносимым условиям. На Руси стремление стать личностью порождало в человеке внутренний конфликт между предопределенностью и свободой, формой решения которого были «уход в пустынь» или «юродство в миру». Архетип «быть как все» трансформировался в «быть не хуже других», отсюда зависть, неприязнь к тем, кто «выше» и сострадание к тем, кто «ниже». На Западе формировалась ориентация личности на лучшие достижения, что требует мобилизации собственного индивидуального потенциала. В результате возникает идеал личности, человека-гражданина с гражданскими правами и свободами, прежде всего, правом собственности и правом выбора. Запад особое внимание уделял индивидуальности, когда вся система ценностей строилась вокруг индивидуума. На Востоке в центре внимания стоит коллективное существование, связанное с природой и общественным образом жизни. В России имело место столкновение этих типов культуры, борьба противоположных начал. На Западе в основе социального регулирования лежит право - выс- 
шая социальная ценность, всеобщий социокультурный регулятор, в России -иерархия, власть, нормы которой устанавливаются "самодержавно», без ограничения извне. В России понятия родины, государства, патриотизма всегда имели огромное значение. Они играли роль мощного национально-объединяющего фактора и обладали огромной организующей силой. Государство и царь стояли выше закона. Неверие в закон вело к правовому нигилизму и произволу, сопровождающемуся азиатской покорностью русского человека. Для русского архетипа свойственна ориентация на авторитет. Но авторитаризм возможен лишь тогда, когда существует общее дело, выраженное в определенной национальной идее, которая выше авторитета, и сам авторитет служит ей. Безусловно, это ведет к двояким последствиям: с одной стороны, вера в авторитет, наделяемый чертами харизматического лидера, а с другой стороны, контроль авторитета через постоянное соотнесение его деятельности с общей идеей, которая сообща переживается людьми. И сегодня мы еще продолжаем искать ответы на вопросы, поставленные в свое время А. Солженицыным в работе «Русский вопрос на рубеже веков»: «Быть ли нам русскими? Если и выживем телесно, то сохраним ли нашу русскость, всю совокупность нашей веры, души, характера, - наш континент во всемирной культурной структуре? Сохранимся ли мы в духе, в языке, в сознании своей исторической традиции»? 